\title{
Some polypores misclassified in Piptoporus
}

\author{
R. GREGTHORN
}

\begin{abstract}
THORN, R.G. 2000: Some polypores misclassified in Piptoporus. - Karstenia 40: 181-187. Helsinki. ISSN 0453-3402.

The taxonomy of six species described in or transferred into the genus Piptoporus was reassessed. Piptoporus choseniae is a Polyporus, and more closely resembles Polyporus pseudobetulinus in morphology and ecology than $P$. varius, to which it has previously been compared and synonymized. Piptoporus fraxineus is Polyporus admirabilis, a holarctic species recently reported from Europe. Piptoporus paradoxus is a later synonym of Piptoporus quercinus, and both were among the three original species of Piptoporus P. Karst. Piptoporus ulmi is allied to Polyporus craterellus and $P$. tuberaster, and is renamed Polyporus vassilievae Thorn, nom. nov. since the epithet ulmi is preoccupied in Polyporus. Piptoporus hirtus is Jahnoporus hirtus, and Piptoporus elatinus (Berk.) Teng, sensu Teng non Berkeley, is Rigidoporus lineatus. Significant range extensions and other ecological aspects of these species are discussed.
\end{abstract}

Key words: biogeography, Polyporus, taxonomy, wood decay fungi

R.G. Thorn, Department of Botany, University of Wyoming, Laramie, WY 820713165, U.S.A.

Present address: Department of Plant Sciences, University of Western Ontario, London, Ontario, N6A B7, Canada

\section{Introduction}

Piptoporus P. Karst. is generally considered to be a small genus of the Polyporaceae surrounding the lectotype species, P. betulinus (Bull. : Fr.) P. Karst. (Ryvarden 1991, Ryvarden \& Gilbertson 1994, Rajchenberg 1994, 1995). Fifteen species names have been proposed in or combined into Piptoporus. The generic placement of several of these has not been critically reassessed. Three species of Piptoporus, $P$. choseniae Vassilkov (1967), P. fraxineus Bondartsev \& Ljubarsky (1965) and P. ulmi Bondartsev \& Ljubarsky (in Bondartsev 1961), were described from Siberia but are poorly known outside their original descriptions in the Russian literature. Type and other specimens were borrowed from the cryptogamic herbarium of the Komarov Botanical Institute, St. Petersburg (LE) and are reported on here. In addition, the combinations Piptoporus paradoxus (Fr.) P. Karst., P. hirtus (Cooke ex Quél.)
Bondartsev \& Ljub. and P. elatinus (Berk.) Teng are discussed. Although $P$. elatinus is now considered a synonym of Tyromyces lacteus (Fr.) Murr. (Ryvarden 1991), the fungus described by Teng $(1939,1964)$ is clearly different. A specimen determined by Teng as Polyporus elatinus in the University of Toronto cryptogamic herbarium (TRTC) was studied to clarify this misapplication.

\section{Materials and methods}

Sections of hymenophore, context and pileipellis were mounted for microscopy in $2 \%(\mathrm{w} / \mathrm{v})$ aqueous $\mathrm{KOH}$ stained with $1 \%$ phloxine, Melzer's reagent (Melzer $1924)$, or $0.05 \%(\mathrm{w} / \mathrm{v})$ Cotton Blue in $85 \%$ lactic acid. Measurements of basidiospores are of shed basidiospores on the pileipellis, mounted in Melzer's reagent. In reporting basidiospore measurements, " $Q$ " is the length to width ratio and figures in parentheses represent the $10 \%$ extremes. Drawings were made with a drawing tube at a final magnification of 3000 times. 


\section{Results}

Polyporus choseniae (Vassilkov) Parmasto, Folia Cryptogam. Estonica 5: 35. 1975, as "chozeniae" Fig. 1

Basionym: Piptoporus choseniae Vassilkov, Nov. Sist. Nizsh. Rast. 4: 244. 1967, as "chozeniae".

Pileipellis a thin cutis of mostly parallel, hyaline, smooth, thin-walled, clamped generative hyphae (2.6-)3.3-6.4(-8.5) $\mu \mathrm{m}$ in diam, collapsing and barely visible with an oil immersion lens and interference contrast; beneath is a subpellis grading into the context dominated by tangled skeletobinding hyphae $2.0-4.5(-5.6) \mu \mathrm{m}$ in diam, tapering to $0.8 \mu \mathrm{m}$ in diam at their tips, with walls

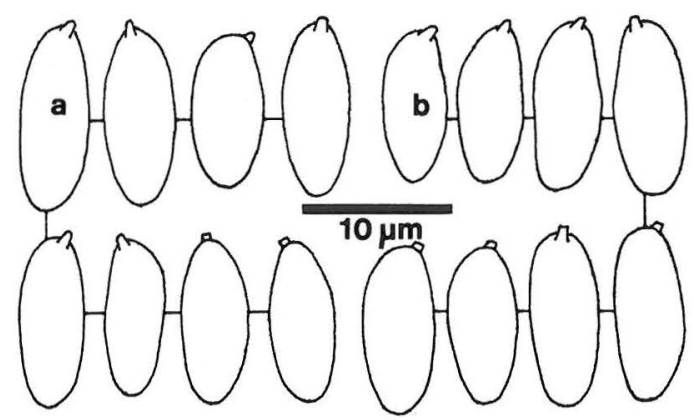

Fig. 1 a-b. Basidiospores of Polyporus choseniae. a from LE 30505, b - from LE 30506.

$0.8-2.6 \mu \mathrm{m}$ thick, many richly branched but others with long unbranched portions; basidiospores (Figs. 1a, b) hyaline, inamyloid, acyanophilous, cylindric to slightly boletinoid, (8.0-) 9.7-12.2(-13.6) × (3.6-)4.1-5.3(-6.1) $\mu \mathrm{m}, \mathrm{Q}=$ $(1.7-) 2.0-2.7(-3.0), \mathrm{n}=164$.

Comments: The spelling of the epithet has been corrected to choseniae to agree with the name of the host genus, Chosenia Nakai (Greuter et al. 1994, recommendation 60H1). Parmasto (1975) compared P. choseniae to Polyporus varius $\mathrm{Fr}$. and $P$. varius var. nummularius (Pers.) Fr., and Nuñez and Ryvarden (1995a) listed it as a synonym of $P$. varius. However, $P$. choseniae is more similar to P. pseudobetulinus (Thorn et al. 1990). Macroscopically, the sessile or substipitate, suberose fruiting bodies lacking a black zone at the point of attachment and soft, medium sized pores (3-4 per $\mathrm{mm}$ ) are characters shared with $P$. pseudobetulinus. In contrast, $P$. varius is centrally to laterally stipitate, with a distinct black stipe base and has minute pores (7-9 per mm) (Gilbertson \& Ryvarden 1987, Ryvarden \& Gilbertson 1994). Microscopically, the basidiospores of $P$. varius are narrower $(9-12 \times 2.5-3$ $\mu \mathrm{m}$, Gilbertson \& Ryvarden 1987; 8.5-11 × 3-3.5 $\mu \mathrm{m}$, Ryvarden \& Gilbertson 1994; 9-12 × 2.5-4 $\mu \mathrm{m}$, Nuñez \& Ryvarden 1995a). Polyporus choseniae differs from $P$. pseudobetulinus in its pileus ornamentation of distinct, dark dots, rather than appressed scales, its clamped generative hyphae, and larger basidiospores $(7.0-9.5 \times 2.5-3.5$ $\mu \mathrm{m}$ in P. pseudobetulinus; Thorn et al 1990). Both species occur on members of the Salicaceae: $P$. pseudobetulinus predominantly on Populus tremula L. in Eurasia and P. balsamifera L. in North America (Thorn et al. 1990) and P. choseniae on Chosenia arbutifolia (Pall.) Skvorts. and rarely Salix sp. (Parmasto 1975).

Specimens examined: Russia. Khabarovsk region, Ola River valley near Magadan, in Chosenia-Salix woods, 16.VIII.1965 B.P. Vassilkov and E.A. Nezdojminogo (LE 22545, holotype). Buryat Republic, Kotelnikovskiy Peninsula near Kurkuly River on northwestern shore of Lake Baikal, 10.VIII.1969 E.A. Nezdojminogo (LE 30505 and 30506).

Polyporus admirabilis Peck, Bull. Torrey Bot. Club 26: 69. 1899. - Figs. 2-3

Polyporus coronadensis R. L. Gilb. \& K. J. Martin, Mycologia 68: 1117. 1976.

Polyporus lowei Burds. \& F. J. Lombard, Mem. N.Y. Bot. Gard. 49:147. 1989, a later homonym of Polyporus lowei (Pilát) Lowe, N.Y. State Coll. For. Tech. Pub. 60: 78. 1942.

Piptoporus fraxineus Bondartsev \& Ljubarsky, Nov. Sist. Nizsh. Rast. (1965):135. 1965. Polyporus fraxineus (Bondartsev \& Ljub.) Y.-C. Dai, Fung. Sci. 14: 69. 1999, a later homonym of Polyporus fraxineus (Bull. : Fr.) Fr., Syst. Mycol. 1:374. 1821.

Pileipellis a cutis of more or less parallel, thinwalled, clamped generative hyphae 1.1-3.6 $\mu \mathrm{m}$ in diam; context dimitic, dominated by nearly solid skeletobinding hyphae (Fig. 2a), some with long unbranched sections and others richly branched, (1.4-)2.0-6.6(-8.8) $\mu \mathrm{m}$ in diam; hymenophoral trama dimitic, dominated by acyanophilous skeletobinding hyphae $1.1-4.8 \mu \mathrm{m}$ in diam, with clamped generative hyphae, showing brilliant purple in Cotton Blue, 1.7-3.0 $\mu \mathrm{m}$ in diam; basidiospores (Fig. 2b) hyaline, inamyloid, acyanophilous, cylindric, with a prominent oblique 


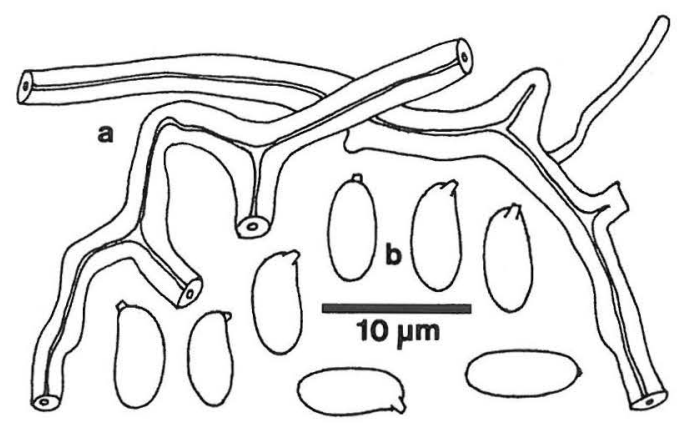

Fig. 2 a-b. Piptoporus fraxineus. a-skeletobinding hyphae from context, and $\mathbf{b}$ - basidiospores, both from LE 22546 (holotype).

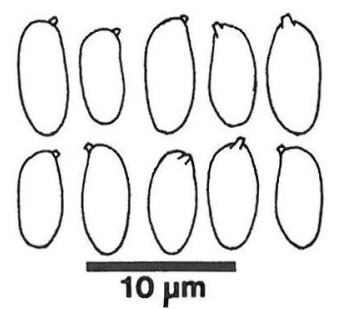

Fig. 3. Polyporus coronadensis basidiospores, from K.J. Martin 110 (isotype, ARIZ).

apiculus, (5.6-)6.6-7.8(-8.0) $\times(2.6-) 2.7-3.4(-3.8)$ $\mu \mathrm{m}, \mathrm{Q}=2.0-2.6(-2.8), \mathrm{n}=22$.

Comments: The holotype specimen of $P$. fraxineus (LE 22546) was also examined and described by Dai \& Niemelä (1995). The portion that I examined had been poorly dried and hymenial features were poorly preserved. As noted by Dai and Niemelä (1995), basidia and most generative hyphae were collapsed, and mature basidiospores were difficult to find, either in the hymenium or on the pileipellis.

This specimen is a substipitate member of Polyporus sensu stricto. The original description and illustration (Bondartsev \& Ljubarsky 1965) and microscopic features identify P. fraxineus as $P$. admirabilis (Peck 1899, Overholts 1953, Gilbertson \& Ryvarden 1987, Nuñez 1994, Ryvarden \& Gilbertson 1994). As mentioned by Nuñez (1994), there are no characters of macroor micromorphology to distinguish $P$. coronadensis or P. lowei Burds. \& F. J. Lombard from $P$. admirabilis. Burdsall and Lombard (1989) stated that $P$. admirabilis has larger pores and narrower skeletobinding hyphae than $P$. lowei, but this is not supported in other descriptions of $P$. admirabilis (Overholts 1953, Gilbertson \& Ry- varden 1987). The basidiospores of $P$. admirabilis are described as 7.5-9 × 2.5-3.5 $\mu \mathrm{m}$ (Overholts 1953), and those of $P$. lowei as $6.5-9 \times 2.5-3 \mu \mathrm{m}$ (Burdsall \& Lombard 1989). Gilbertson and Martin (1976) reported the basidiospores of $P$. coronadensis as 7-10 × 2.5-3.5 $\mu \mathrm{m}$, whereas Gilbertson and Ryvarden (1987) reported them as 7-7.5 $\times 2.5-3 \mu \mathrm{m}$. In two collections of $P$. coronadensis that I examined, shed basidiospores on the pileipellis were found to be (5.9-)6.4-8.0(-8.7) $\times$ (2.7-)3.0-3.6(-3.8) $\mu \mathrm{m}, \mathrm{Q}=(1.9-) 2.0-2.4(-2.7), \mathrm{n}$ $=80$ (Fig. 3). Thus, the basidiospores of these taxa appear to be indistinguishable. Polyporus admirabilis has been recorded on Acer, Betula, Fraxinus, Juglans, Malus, Quercus and Salix in eastern North America (Michigan to Maine; Overholts 1953, Burdsall \& Lombard 1989, Gilbertson \& Ryvarden 1987), on Quercus in Arizona (Gilbertson \& Martin 1976), on Malus and Quercus in Norway (Nuñez 1994), in Japan (substrate of cited collection not mentioned; Nuñez \& Ryvarden 1995b), on Fraxinus in eastern Siberia (Bondartsev \& Ljubarsky 1965), and on Ulmus and Quercus in northeastern China (Dai 1996, 1999). More collections, especially from Siberia, and cultural studies would help to resolve the relationships of these disjunct collections. Nuñez and Ryvarden (1995a) also list Polyporus underwoodii Murr. and $P$. pennsylvanicus Sumstine as synonyms of $P$. admirabilis.

Burdsall and Lombard (1989) described cultures of this species, as $P$. lowei.

Specimens examined: Piptoporus fraxineus: Russia. Primorye Territory, dist. Nadezhdinskiy [Shkotovskiy], Maykhinskiy experimental forest, near Peyshula in Maykhe River valley, 1.VIII.1960 L.V. Ljubarsky (LE 22546, holotype). Polyporus coronadensis: U.S.A.: Arizona, Cochise Co., Coronado National Forest, 17.VIII.1971 K.J. Martin 110 (AN 010680, ARIZ, isotype); Gila Co., Tonto National Forest, 26.VIII.1977 K.J. Martin 527 (AN 010683, ARIZ).

Piptoporus quercinus (Schrad.) P. Karst., Medd. Soc. F. Fl. Fenn. 6: 9. 1881. - Fig. 4

Basionym: Boletus quercinus Schrad., Spicil. Fl. German. p. 157, 1794. - Polyporus quercinus (Schrad.) Fr., Epicr.: 441. 1838. - Buglossoporus quercinus (Schrad.) Kotl. \& Pouzar, Ceská Mykol. 20: 84. 1966.

Boletus pulvinus Pers., Obs. Mycol. 2: 7. 1800. - Buglossoporus pulvinus (Pers.) Donk, Proc. K. Nederl. Akad. Wet. C 74: 4. 1970.

Polyporus paradoxus Fr., Öfversigt Kongl. Vet.-Akad. Förh. 5: 8. 1873. - Piptoporus para- 
doxus (Fr.) P.Karst., Medd. Soc. F. Fl. Fenn. 6: 9. 1881.

The original description of Piptoporus (Karsten 1881) included three species: $P$. betulinus, $P$. paradoxus, and $P$. quercinus. Two are well known: $P$. betulinus was designated as lectotype of Piptoporus (Donk 1960), and P. quercinus is generally accepted in Piptoporus (but the combination in Piptoporus is often incorrectly attributed to Pilát, e.g., Ryvarden \& Gilbertson 1994) or placed in Buglossoporus Kotl. \& Pouzar (Kotlaba \& Pouzar 1966). Piptoporus paradoxus was based on a single collection, now lost, and no other specimens are known. I argue herein that $P$. paradoxus represents a later synonym of $P$. quercinus.

Polyporus paradoxus was described on the basis of a specimen from Sparreholm, Södermanland, Sweden, on unidentified wood ("ad truncos arborum;" Fries 1873). The unpublished painting of $P$. paradoxus by J. Malmberg and authorized by E. Fries (in S) depicts the holotype specimen, which was not found among Fries' collections in Lund, Stockholm or Uppsala. This painting (Fig. 4) must therefore be considered the iconotype for $P$. paradoxus. The original description (Fries 1873) and painting (Fig. 4) indicate a massive, dimidiate-subimbricate, alutaceous fruiting body, with white pores that stain blackish on bruising. The latter character is also found in P. quercinus (Ryvarden \& Gilbertson 1994), which is also indicated by the description (Fries 1873) of the pileus surface ("non quidem villosus, sed cuticula e floccis laevigatus contexta") and context ("floccosa, molissima"). I initially considered Polyporus paradoxus as a possible earlier name for $P$. admirabilis on the basis of the similar macromorphology, but this synonymy is ruled out by these same descriptive phrases. The cuticle of $P$. admirabilis is glabrous and pelliculose, and the context, as in most true Polyporus species, is softpliant to corky (Gilbertson \& Ryvarden 1987). Bourdot and Galzin (1928) and Donk (1974) believed that $P$. paradoxus was synonymous with Piptoporus soloniensis (Dubois : Fr.) Pilát. The blackish bruising of the hymenophore could also suggest Meripilus giganteus (Pers. : Fr.) P. Karst., but the illustration (Fig. 4) rules out both of these species.

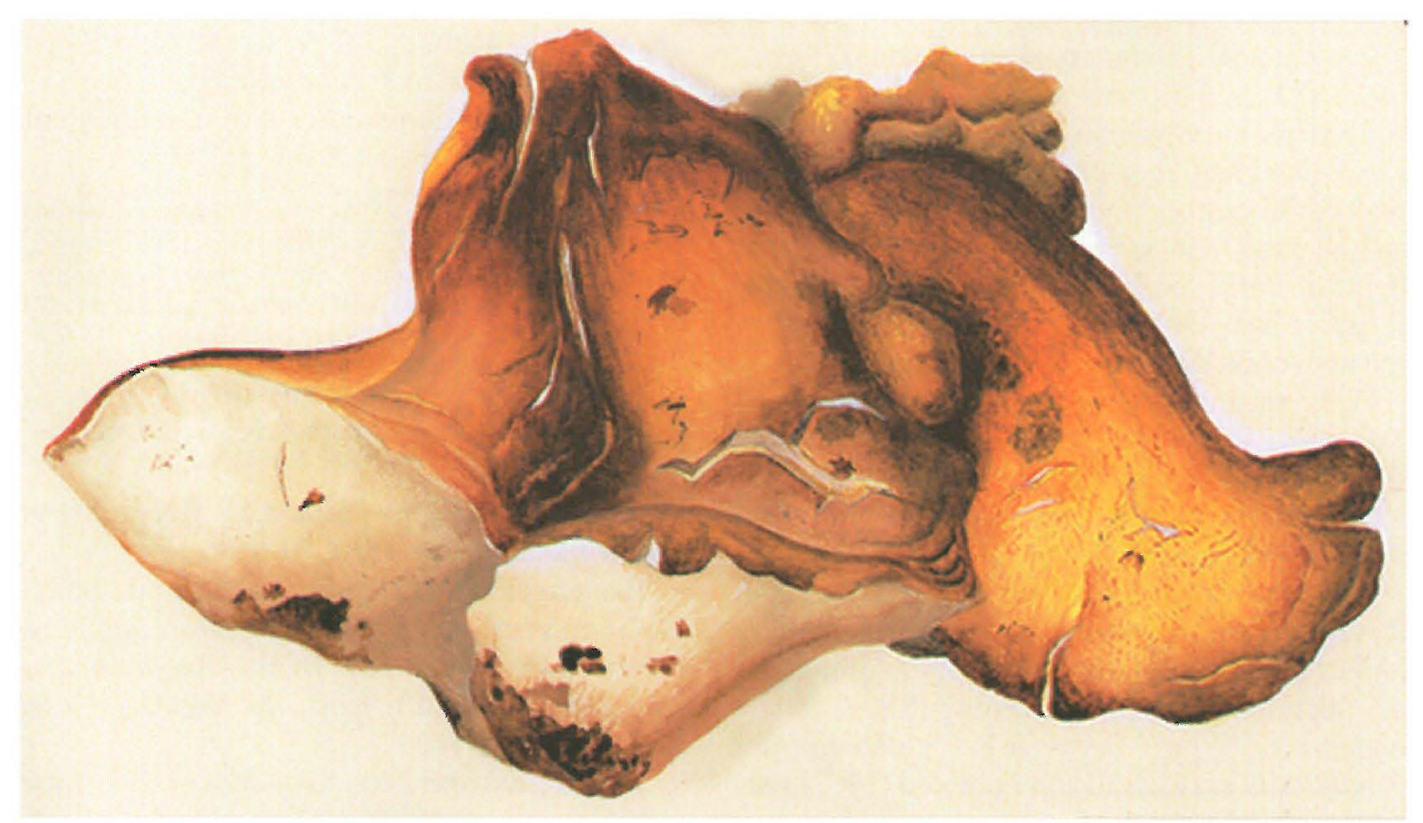

Fig. 4. Polyporus paradoxus. This is a reproduction of the iconotype, an unpublished painting by Malmberg of the holotype (only collection cited in protologue), which was authorized by E.M. Fries. In the original, the combined fruiting bodies are $33 \mathrm{~cm}$ broad. 
This rare species is most commonly referred to in recent literature as Buglossoporus pulvinus. The genus Buglossoporus is distinguished from Piptoporus by monomitic hymenophoral trama, compared to dimitic in Piptoporus betulinus, and unbranched (versus branched) skeletal hyphae. If additional characters, including sequence data, support the distinction of Buglossoporus, the correct (older) species name is $B$. quercinus.

\section{Polyporus vassilievae Thorn, nom. nov. - Fig. 5}

Piptoporus ulmi Bondartsev \& Ljub. in Bondartsev, Bot. Mater. (Not. syst. Sect. crypt. Inst. bot. Acad. Sci. USSR) 14: 198. 1961. - Polyporus ulmi (Bond. \& Ljub.) Vassilkov, Nov. Sist. Nizsh. Rast. 4: 246. 1967, a later homonym of Polyporus ulmi Paulet, Icon. Champ. pl. 13. 1812.

Etymology: Named for L.N. Vassiljeva, collector of the holotype.

Pileipellis a cutis of parallel, thin-walled, smooth or finely granule-encrusted, clamped generative hyphae (1.9-)2.2-6.7(-8.4) $\mu \mathrm{m}$ in diam; below this a tangled subpellis; context dimitic, dominated by non-taining skeletobinding hyphae (Fig. 5a), with distant branching, 1.87.0(-9.4) $\mu \mathrm{m}$ in diam, with walls $0.8-2.4 \mu \mathrm{m}$ thick, and with clamped, thin-walled generative hyphae $1.9-4.4 \mu \mathrm{m}$ in diam and clamped, thin-walled gloeoplerous hyphae (Fig. 5c), the latter brownish yellow in $\mathrm{KOH}$ and deeply stained in Cotton Blue, 4-10(-13.3) $\mu \mathrm{m}$ in diam; hymenophoral tra$m a$ dimitic, with scarcely branched skeletobinding hyphae $1.7-4.4 \mu \mathrm{m}$ in diam, with non-staining walls $0.7-1.8 \mu \mathrm{m}$ thick, clamped generative hyphae $1.4-5.3 \mu \mathrm{m}$ in diam and scattered gloeoplerous hyphae to $12.6 \mu \mathrm{m}$ in diam; basidia cylindricclavate, 4-spored, 25.3-33.6 × 8.5-9.4 $\mu \mathrm{m}$; cystidia lacking; basidiospores (Fig. 5b, d) hyaline, inamyloid, acyanophilous, cylindric, with slight suprahilar depression and oblique apiculus, (8.6-)9.6-12.3(-14.6) × (3.3-)4.0-4.9(-5.5) $\mu \mathrm{m}, \mathrm{Q}$ $=(1.9-) 2.2-2.8(-3.2), \mathrm{n}=103$.

Comments: Although the portion of the holotype examined was in crumbs and difficult to reinterpret macroscopically, the microscopic features are well preserved and it is amply fertile. This is a species of the genus Polyporus sensu stricto, microscopically identical to $P$. craterellus Berk. \& Curt., including basidiospore size and the presence of gloeoplerous hyphae (Gilbertson \& Ryvarden 1987). However, the original description (Bondartsev \& Ljubarsky, in Bondartsev
1961) serves to distinguish this species from $P$. craterellus by its stouter fruiting bodies with much thicker pileus, described as $2-3.5 \mathrm{~cm}$ thick at the center. Polyporus craterellus is described by Overholts (1953, as P. fagicola Murr.) and by Gilbertson \& Ryvarden (1987) as having a thin pileus, 2-5 mm thick, and growing on Acer, Fagus and Platanus in eastern North America. The stout stature and many other features of macroand micromorphology are shared with $P$. tuberaster, which is readily distinguished by its occurrence on the ground (fruiting from a buried sclerotium) and its broader basidiospores (10-16 × 4.5-7 $\mu \mathrm{m}$; Nuñez \& Ryvarden 1995a).

Specimens examined: Russia. Primorye Territory, dist. Voroshilovskiy, Suputinskiy Reservation, VIII.1945 L.N. Vassiljeva (LE 22548, holotype); Maykhinskiy experimental forest, 23.VII.1949 L.V. Ljubarsky (LE 30529). Label data for two additional collections (not seen) were sent by V. Mel'nik: Suputinskiy Reservation, 24.VIII.1946 L.N. Vassiljeva (LE 30528) and Amurskaya Oblast, dist. Arkharinskiy, Uril forest, 20.VIII.1959 Drozdova (LE 22547).

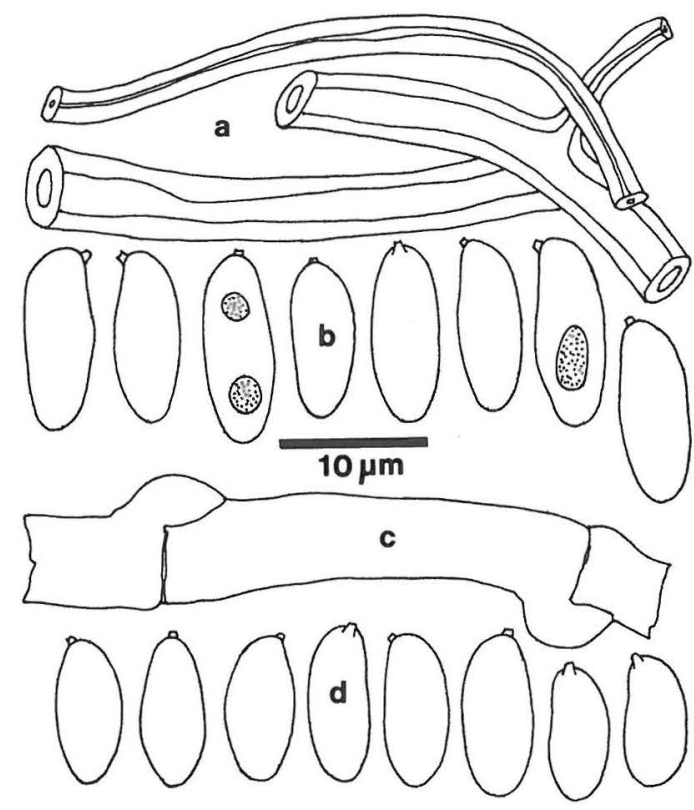

Fig. 5 a-d. Polyporus vassilievae (Piptoporus ulmi). a skeletobinding hyphae from context, $\mathbf{b}-$ basidiospores, $\mathbf{c}$ - gloeoplerous hyphae, and $\mathbf{d}$ - basidiospores. $\mathrm{a}$ and $\mathrm{b}$ from LE 22548 (holotype), c and d from LE 30529. 
Jahnoporus hirtus (Cooke ex Quélet) Nuss, Hoppea 39: 176. 1980.

Piptoporus hirtus (Cooke ex Quél.) Bondartsev \& Ljub. in Ljubarsky, Bot. Mater. (Not. syst. Sect. crypt. Inst. bot. Acad. Sci. USSR) 15: 123. 1962.

For additional synonymy see Nuss (1980) and for a description see Nuss (1980), Gilbertson and Ryvarden (1986), or Ryvarden and Gilbertson (1993). This species differs from Piptoporus in causing a white rot, being monomitic, and having large, fusoid basidiospores (Gilbertson \& Ryvarden 1986). Ljubarsky (1962) reported four collections from the Primorye Territory, in upland forests of Picea jezoensis (Siebold \& Zucc.) Carr. and Abies nephrolepis (Trautv.) Maxim. The description by Ljubarsky (1962) refers to this species, which has been adequately treated in recent literature. Jahnoporus hirtus has been reported from mountainous or northern coniferous forests of eastern and western North America, western Europe, and Japan (Gilbertson \& Ryvarden 1986, Jülich 1984, Ryvarden \& Gilbertson 1993).

Rigidoporus lineatus (Pers.) Ryvarden, Norw. J. Bot. 19: 236. 1972. - Fig. 6

Misapplication: Piptoporus elatinus (Berk.) Teng, Chung-kuo ti Chen-chun 762. 1964, sensu

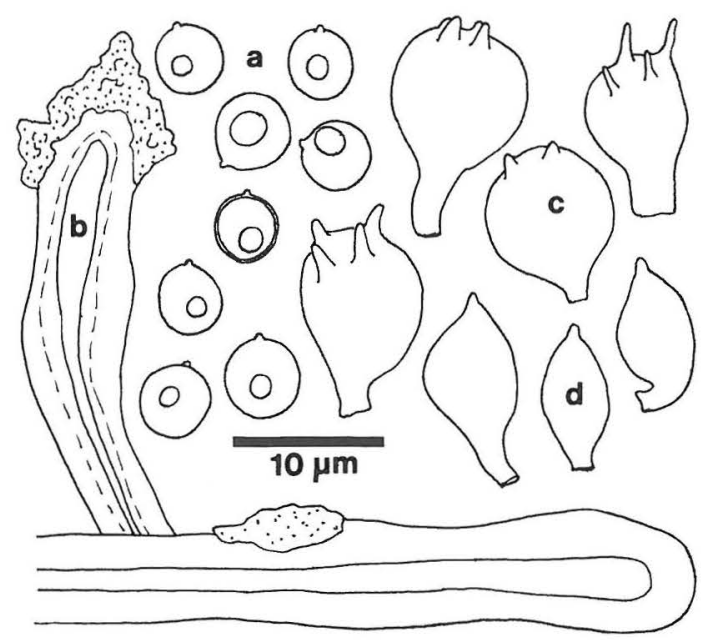

Fig. 6 a-d. Rigidoporus lineatus (Piptoporus elatinus sensu Teng). $\mathbf{a}$ - basidiospores, $\mathbf{b}$ - pseudocystidia, $\mathbf{c}-$ basidia, and $\mathbf{d}$ - cystidioles, all from Teng 3313 (TRTC 2042).
Teng (1964: 510; 1939: 391, as Polyporus elatinus) non Berkeley (1854).

Teng $(1939,1964)$ misapplied the name Polyporus elatinus. His description (1964), is here paraphrased in translation, with additional data from TRTC 2042 in square brackets: Pilei suspended beneath the wood, rounded or kidneyshaped in outline, 1-6 cm broad, often connected, with thin, distinct cuticle, glabrous, with either radial or indistinct concentric lines or wrinkles, light crab-apple on the top to dark egg-shell at the edge; edge thin, sharp, incurved; context nearly white, $1-1.5 \mathrm{~mm}$ thick; tubes $1.5-3.5 \mathrm{~mm}$ long, slightly darker than context, easily separable; pores dark, angular, 10-12/mm; basidiospores (Fig. 6a) spherical, hyaline, [inamyloid, with distinctly cyanophilous walls $0.2-0.4 \mu \mathrm{m}$ thick], smooth, 4-5 $\mu \mathrm{m}$ in diam [(4.1-)4.2-5.2 $(-5.9)(3.7-) 3.9-4.8(-5.2) \mu \mathrm{m}, \mathrm{Q}=1.0-1.2(-1.3)$, $\mathrm{n}=42$ ], with one large guttule; [ context and trama monomitic, but with both thin and thick-walled, simple-septate generative hyphae, $(2-) 3-7(-12)$ $\mu \mathrm{m}$ in diam, the context dominated by thickwalled hyphae; pileipellis a palisade of thickwalled, sphaeropedunculate cells 5.7-14 $\mu \mathrm{m}$ broad, with walls 1.4-3.2 $\mu \mathrm{m}$ thick; pseudocystidia (Fig. 6b) embedded in the hymenium, tubular, thick-walled, apically encrusted, $5-8 \mu \mathrm{m}$ in diam; basidia (Fig. 6c) broadly clavate to sphaeropedunculate, 4-spored, 10.5-15 × 8-9 $\mu \mathrm{m}$; cystidioles (Fig. 6d) fusoid-mucronate, thin-walled, $8-10 \times 3-5 \mu \mathrm{m}$.]

Specimen examined: China. Hainan, Yen-hsien, 11.VI.1934 S.Q. Deng (= S.C. Teng) 3313 (TRTC 2042).

Comments: The monomitic context of simpleseptate, thin and thick-walled hyphae, the reddish coloration of both the upper surface of the pileus and the pore layer, the encrusted, thickwalled pseudocystidia, and the globose to subglobose basidiospores identify this specimen as Rigidoporus lineatus (Pers.) Ryv., a fungus which is widespread in the tropical and subtropical regions of the world (Gilbertson \& Ryvarden 1987). Zhao and Zhang (1992) also reported $R$. lineatus from Hainan, but did not treat the name Piptoporus elatinus. Ryvarden (1991) lists Polyporus elatinus as a synonym of Tyromyces lacteus. 
Acknowledgements: It is a pleasure to thank V. Mel'nik (LE), R.L. Gilbertson (ARIZ), and J. Krug (TRTC) for providing type and other specimens for study, N.G. Lundqvist and A.. Strid (S) for providing a digital image, photocopy and description of the unpublished painting of P. paradoxus, J.H. Ginns (DAOM) and A.Y. Rossman (BPI) for providing copies of obscure taxonomic literature, $\AA$. Strid for information regarding the collecting locality of $P$. paradoxus and its possible synonymy with P. quercinus, and Y.-C. Dai for sharing the proofs of his 1999 paper. Part of this research was done in the lab of D.W. Malloch (University of Toronto) while the author was supported by an NSERC (Canada) graduate fellowship. Pre-submission reviews were provided by J.H. Ginns and R.H. Petersen.

\section{References}

Berkeley, M.J. 1854: Decades of fungi. Decades XLIXLIII. Indian fungi. - Hook. J. Bot. 6: 129-143.

Bondartsev, A.S. 1961: Species nonnullae Polyporaceae curiosae orientis extremi.- Bot. Mater. (Not. Syst. Sect. Crypt. Inst. Bot. Acad. Sci. USSR) 14:198-206.

Bondartsev, A.S. \& Ljubarsky, L.V. 1965: Species nonnullae Polyporaceae novae orientis extremi. - Nov. Sist. Nizsh. Rast. (1965): 135-147.

Bourdot, H. \& Galzin, A. 1928: Hyménomycètes de France. - Société Mycologique de France, Sceaux. 764 pp.

Burdsall, H.H., Jr. \& Lombard, F.J. 1989: Polyporus 1owei, a new species from the Great Lakes region. Mem. N.Y. Bot. Gard. 49: 147-151.

Dai, Y.-C. 1996: Changbai wood-rotting fungi 7. A checklist of the polypores. - Fung. Sci. 11: 79-105.

Dai, Y.-C. 1999: Changbai wood-rotting fungi 11. Species of Polyporus sensu stricto. - Fung. Sci. 14: 6778.

Dai, Y.-C. \& Niemelä, T. 1995: Changbai wood-rotting fungi 4. Some species described by A.S. Bondartsev and L.V. Lyubarsky from the Russian Far East. - Ann. Bot. Fennici 32: 211-226.

Donk, M.A. 1960: The generic names proposed for Polyporaceae. - Persoonia 1: 173-302.

Donk, M.A. 1974: Check list of European polypores. North-Holland Publishing Company, Amsterdam. 469 pp.

Fries, E.M. 1873: Decas Hymenomycetum novorum. Öfversigt af Kongl. Vetenskaps-Akademiens Förhandlingar 1873 (5): 3-9.

Gilbertson, R.L. \& Martin, K.J. 1976: Polyporus coronadensis, a new species from Arizona. - Mycologia 68: $1116-1120$.

Gilbertson, R.L. \& Ryvarden, L. 1986: North American polypores 1. - Fungiflora, Oslo. $433 \mathrm{pp}$.

Gilbertson, R.L. \& Ryvarden, L. 1987: North American polypores 2. - pp. 434-885. Fungiflora, Oslo.

Greuter, W. et al. 1994: International code of botanical nomenclature (Tokyo code). - Reg. Veget. 131: ixviii, $1-389$.
Jülich, W. 1984: Die Nichtblätterpilze, Gallertpilze und Bauchpilze. - IGams, H. (ed.), Kleine Kryptogamenflora, Band II b/1. - Gustav Fischer Verlag, Stuttgart. 626 pp.

Karsten, P.A. 1881: Symbolae ad mycologiam fennicam VIII. - Medd. Soc. F. Fl. Fenn. 6: 7-13.

Kotlaba, F. \& Pouzar, Z. 1966: Buglossoporus gen. nov. - a new genus of polypores. - Česká Mykol. 11: 152170.

Ljubarsky, L.V. 1962: Polypori nonnulli rari ex oriente extremo. - Bot. Mater. (Notul. Syst. Sect. Cript. Inst. Bot. Acad. Sci. U.S.S.R.) 15: 111-125.

Melzer, V. 1924: L'ornementation des spores des Russules. - Bull. Soc. Mycol. France 40: 78-81.

Nuñez, M. 1994: Polyporus admirabilis (Polyporaceae), new to Europe. - Karstenia 34: 1-3.

Nuñez, M. \& Ryvarden, L. 1995a: Polyporus (Basidiomycotina) and related genera. - Synopsis Fungorum 10: $1-85$.

Nuñez, M. \& Ryvarden, L. 1995b: Polypores new to Japan 1. Species of Polyporus, with a note on P. hartmanni. - Mycoscience 36: 61-65.

Nuss, I. 1980: Untersuchungen zur systematischen Stellung der Gattung Polyporus. - Hoppea 39: 127-198.

Overholts, L.O. 1953: The Polyporaceae of the United States, Alaska and Canada. - University of Michigan Press, Ann Arbor. 466 pp.

Parmasto, E. 1975 ("1974"): On Polyporus chozeniae (Vassilk.) Parm. comb. nov. and related species. - Folia Cryptogam. Estonica 5: 35-39.

Peck, C.H. 1899: New species of fungi. - Bull. Torrey Bot. Club 26: 63-71.

Rajchenberg, M. 1994: A taxonomic study of the subantarctic Piptoporus (Polyporaceae, Basidiomycetes) I. - Nord. J. Bot. 14: 435-449.

Rajchenberg, M. 1995: A taxonomic study of the subantarctic Piptoporus (Polyporaceae, Basidiomycetes) II. - Nord. J. Bot. 15: 105-119.

Ryvarden, L. 1991: Genera of Polypores: nomenclature and taxonomy. - Synopsis Fungorum 5, Fungiflora, Oslo. 363 pp.

Ryvarden, L. \& Gilbertson, R.L. 1993: European polypores. Part 1. - Fungiflora, Oslo. 387 pp.

Ryvarden, L. \& Gilbertson, R.L. 1994: European polypores. Part 2. - pp. 388-743. Fungiflora, Oslo.

Teng, S.C. 1939: A Contribution to our knowledge of the higher fungi of China. - National Institute of Zoology and Botany, Academia Sinica, Beijing. 614 pp.

Teng, S.C. 1964: Chung-kuo ti Chen-chun. - [Academic Press], Beijing. 808 pp.

Thorn, R.G., Kotiranta, H. \& Niemelä, T. 1990: Polyporus pseudobetulinus comb. nov.: new records in Europe and North America. - Mycologia 82: 582-594.

Vassilkov, B.P. 1967: Species nova familiae Polyporaceae in Chozenia macrolepis (Turcz.) Kom. - Nov. Sist. Nizsh. Rast. [4] (1967): 244-246.

Zhao, J.-D. \& Zhang, X.-Q. 1992: The polypores of China. - Bibl. Mycol. 145: 1-524. 